\title{
On board recognition of different fuels in SI engines with the use of dimensional and non-dimensional vibration signal parameters
}

\begin{abstract}
Gaseous fuels such as natural gas and propane butane mixtures are currently the most popular fuels for dual fuel internal combustion engines. Gaseous fuels are more resistant to knocking than conventional liquid fuels they mix better with air. There have been many published works on the use of gaseous fuels but the problem of the combustion noise, as a very important source of acoustic discomfort is not getting enough attention. Combustion noise occurs in a direct and indirect form. It is transmitted throughout the engine block as a vibration at a different spectrum of frequencies. In this study an attempt has been made to correlate the combustion noise with the operating parameters of an engine fueled with $L P G, C N G$ and CNG-hydrogen mixtures as compared to petrol fueled engine. Signals of multiple resonance in the combustion chamber and corresponding vibration signals of the cylinder block of engine have been considered for one combustion cycle. A four cylinder, $1.6 \mathrm{dm}^{3}$ spark-ignition engine converted to run on $L P G, C N G$ and CNG-hydrogen mixtures has been tested in the project. A well known diagnostic parameter was used for comparison of the engine noise for its operation on gasoline and alternative fuels. A new non-dimensional indicator has also been proposed for the engine vibration estimation purposes the Increase Wavelet Ratio $C^{\prime}{ }_{a b}$, precisely described in the paper.
\end{abstract}

Key words: alternative fuels, engine vibration, dimensional and non-dimensional indicators

\section{Rozpoznawanie paliw zasilających silnik przy użyciu wymiarowych i bezwymiarowych wskaźników sygnału przyspieszeń drgań}

\begin{abstract}
Paliwa gazowe, takie jak mieszanki propanu butanu czy gaz ziemny sq obecnie najpopularniejszymi paliwami zasilającymi silniki spalinowe. Paliwa gazowe znane sa z większej odporności na spalanie detonacyjne niż paliwa płynne oraz łatwiejszego wymieszania z powietrzem. Wiele prac poświecono zasilaniu silników paliwami gazowymi, lecz problemu hałasu w trakcie spalania, jako bardzo ważnego źródła dyskomfortu, do tej pory nikt nie rozpatrywał. Hałas procesu spalania można podzielić na wewnętrzny i zewnętrzny. Wewnętrzny hałas jest transmitowany przez ścianki bloku silnika przy różnej częstotliwości. W artykule przedstawiono wyniki analiz sygnału drganiowego ścianki bloku silnika przy zasilaniu różnymi paliwami. Silnik o ZI o pojemności 1,6 $\mathrm{dm}^{3}$ przystosowano do zasilania paliwem LPG, CNG oraz mieszankami CNG i wodoru. Przeprowadzono badania wpływu obciażenia i prędkości obrotowej na poziom drgań bloku silnika. Do oceny wyników badań użyto znanego wskaźnika bezwymiarowego. W artykule zaproponowano także nowy wskaźnik bezwymiarowy do oceny drgań bloku silnika. Jest to przyrost wspótczynnika falkowego $C_{a b}{ }^{\text {. }}$

Słowa kluczowe: drgania silnika, diagnostyka, wymiarowe i bezwymiarowe wskaźniki, przyrost wspótczynnika falkowego
\end{abstract}

\section{Introduction}

The main goal of the research program connected with the combustion process validation was to design a real time combustion process control system using vibration analysis methods. In-cylinder transformation of chemical energy into mechanical energy is a complicated process. Direct indicated pressure measurements are also very expensive.

According to the research that has already been done [1, $2]$, there is a close correlation between combustion process represented by means of indicated pressure, and engine block vibrations.

Vibration processes that are common for engine operation, constitute a cycle of repeated sequences in time. The following sequence does not match the previous one when the field phenomenon components are taken into account.

Basic four stroke engine operating cycle is completed with two crankshaft revolutions.

The combustion process validation on the basis of registered vibration signals requires an identification of

\section{Wprowadzenie}

Najważniejszym celem przedstawionego programu badań procesu spalania było zaprojektowanie systemu kontroli procesu przy użyciu sygnałów wibroakustycznych. Transformacja energii chemicznej wewnątrz cylindra na energię mechaniczną jest procesem złożonym i skomplikowanym. Bezpośredni pomiar ciśnienia wewnątrz cylindra jest nadal procesem drogim.

Badania wykonane w ostatnim czasie $[1,2]$ wskazują na korelację pomiędzy procesem spalania, reprezentowanym przez wartość ciśnienia indykowanego, i drganiami korpusu silnika.

Procesy wibroakustyczne, które są wspólne dla pracującego silnika, tworzą cykliczne, powtarzalne w czasie sekwencje, przy czym każda następna sekwencja nie jest podobna do poprzedniej, gdzie zakres składowych jest poddawany analizie.

Podczas pracy czterosuwowego silnika wał korbowy pokonuje dwa pełne obroty w trakcie jednego cyklu roboczego. 
the engine block resonance frequencies [3]. A definition of spectral transfer functions for the chosen test points makes the analysis of the results easier and enables an optimal location of the sensors on the engine block.

The combustion process analysis with the use of vibroacoustic methods is very complex and difficult particularly in terms of the necessary analysis of non-stationary and cyclostationary signals. The initial test results of the influence of a fuel type on the indicated pressure and engine block vibrations have been presented in this paper.

\section{Experimental setup}

The evaluation of the engine block vibration level was done with the use of selected diagnostic factors. Their values, calculated separately for different operating conditions of engine fueled by different fuels, suggest their possible application in recognizing the engine fuel the engine. The factors applied in the project for engine block vibration signal analysis are shown below. The first is a scalogram represented by the following equation:

$$
\operatorname{SCAL}_{\mathrm{f}}(\mathrm{a}, \mathrm{b})=\left|\mathrm{C}_{\mathrm{ab}}\right|^{2}
$$

where: $\mathrm{C}_{\mathrm{ab}}$ - wavelet coefficient.

Second, the Increase Wavelet Ratio $\mathrm{C}^{\text {, }}$ ab may be estimated as follows:

$$
\mathrm{C}_{\mathrm{ab}}^{\prime}=\frac{\mathrm{dC}_{\mathrm{ab}}}{\mathrm{d} \alpha}
$$

Both factors are calculated from wavelet coefficient traces.

\section{Test setup}

The tested object was a $1.6 \mathrm{dm}^{3}$ SI engine, fueled with gasoline and gaseous fuels. During the test procedure the indicated pressure in the $4^{\text {th }}$ cylinder and the vibration acceleration in four points on the engine block were registered in two series.

For each of the fuels, the acquisition procedure registrations were made in the time domain with the use of two transducers. Transducers were registering the vibrations accelerations in the $y$ and $x$ axes in the $4^{\text {th }}$ cylinder zones. The test procedure was done with the use of a pressure transducer type 6121 working together with a charge amplifier 5011, crankshaft position sensor type 2613B by Kistler and acceleration transducers ICP from PCB together with Roga Instruments signal amplifier type PA3000. Signals were acquired with the use of eight channels PCI card by National Instruments (NI PCI-6143) controlled by an application written in LabView environment.

The variations of both load and speed of the tested engine were completed on a BOSCH FLA 203 roller bench. Figure 1 shows the diagram of dataflow in the described system.
Weryfikacja procesów spalania na podstawie zarejestrowanych przebiegów sygnałów drgań wymaga identyfikacji częstotliwości rezonansowych korpusu silnika [3]. Definicja funkcji przejścia dla wybranych punktów pozwoliła na łatwą analizę wyników badań dzięki optymalnej lokalizacji przetworników drgań na korpusie silnika.

Analiza procesu spalania przy użyciu metod wibroakustycznych jest bardzo skomplikowana i trudna, zwłaszcza gdy bierze się pod uwagę niezbędne do analizy sygnały niestacjonarne i cyklostacjonarne. $\mathrm{W}$ artykule przedstawiono początkowe badania wpływu rodzaju paliwa na wartość ciśnienia idykowanego i drgania korpusu silnika.

\section{Stanowisko badawcze}

Do określenia poziomu drgań bloku silnika użyto wybrane współczynniki diagnostyczne. Ich wartości obliczono dla każdych warunków zasilania silnika różnym rodzajem paliwa, sugerując ich możliwe zastosowanie do rozpoznawania rodzaju paliwa zasilającego. Estymaty zastosowane do analizy drgań korpusu silnika przedstawiono niżej. Pierwszym jest skalogram reprezentowanym przez równanie (1), gdzie: $\mathrm{C}_{\mathrm{ab}}-$ współczynnik falkowy.

Drugi to przyrost współczynnika falkowego $\mathrm{C}^{\prime}{ }_{\mathrm{ab}}$, który może być oszacowany równaniem (2). Oba współczynniki są obliczane z rozkładu współczynników falkowych.

\section{Aparatura pomiarowa}

Obiektem badań był silnik o ZI o pojemności $1,6 \mathrm{dm}^{3}$ zasilany paliwem benzynowym oraz paliwami gazowymi. Podczas badań równolegle rejestrowano ciśnienie w czwartym cylindrze oraz drgania korpusu silnika.

Dla każdego paliwa akwizycja sygnałów drgań odbywała się w dziedzinie czasu przy użyciu dwóch przetworników. Przetworniki rejestrowały przyspieszenia drgań w płaszczyźnie x i y w pobliżu czwartego cylindra. Badania wykonano przy użyciu przetwornika ciśnienia typu 6121 współpracującego ze wzmacniaczem ładunku 5011, pozycję wału korbowego mierzono za pośrednictwem czujnika typu 2613B firmy Kistler, natomiast przetworniki przyspieszeń

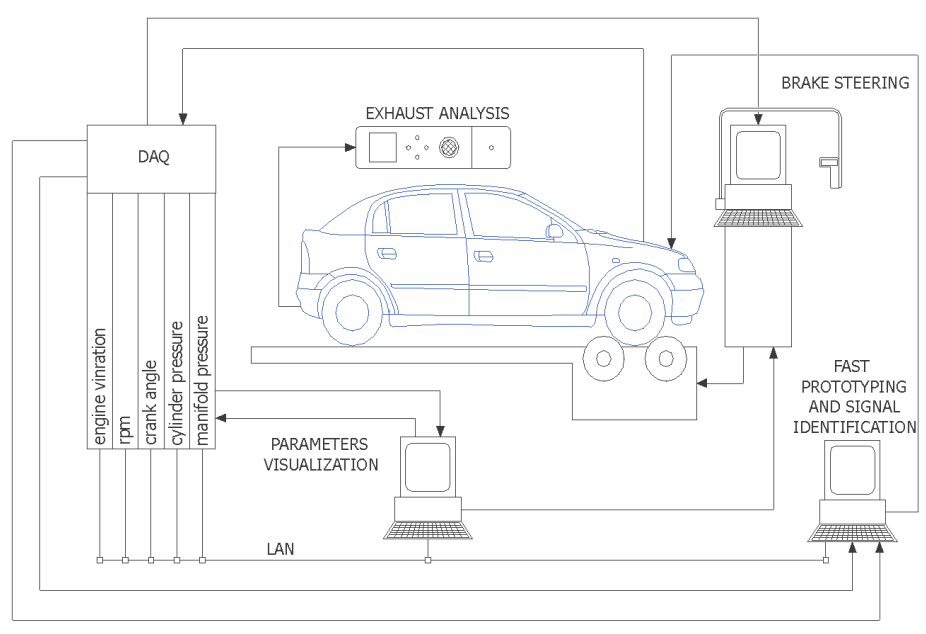

Fig. 1. Schematic diagram of the experimental setup Rys. 1. Schemat stanowiska pomiarowego 


\section{Results and discussion}

The combustion pressure is one of the main factors determining the engine block vibrations. Figure 3 presents the engine cycle hardness as a representative excitation for different fuels.

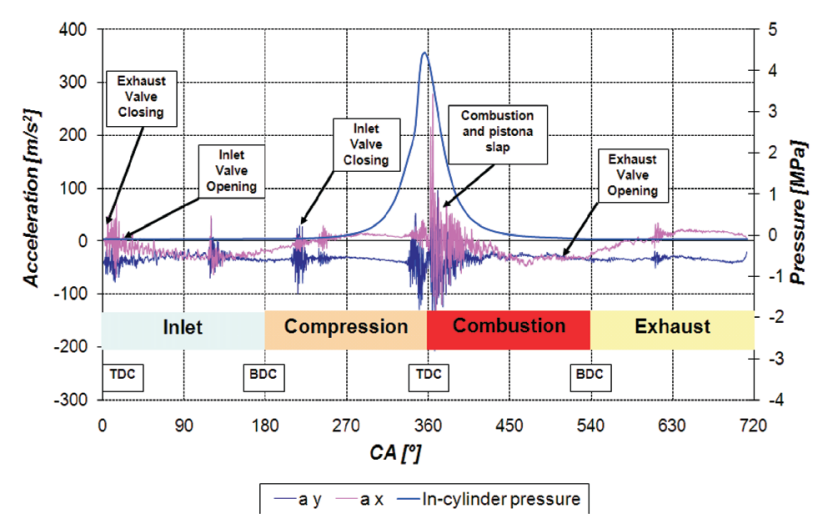

Fig. 2. Engine block acceleration phenomena

Rys. 2. Zjawiska wibroakustyczne zachodzace w silniku spalinowym

The variation of those shocks complicates the analysis of the combustion process based on the vibration signals. This determines the necessity of using complex signal processing methods in either the time or the angular domain.

Alternative gaseous fuels, currently very popular, burn differently than it is in the case of gasoline. From the research that has been done, it can be noticed that gaseous fuels quickly and completely mix with air, thus giving more homogenous mixtures enabling its more even distribution to all cylinders.

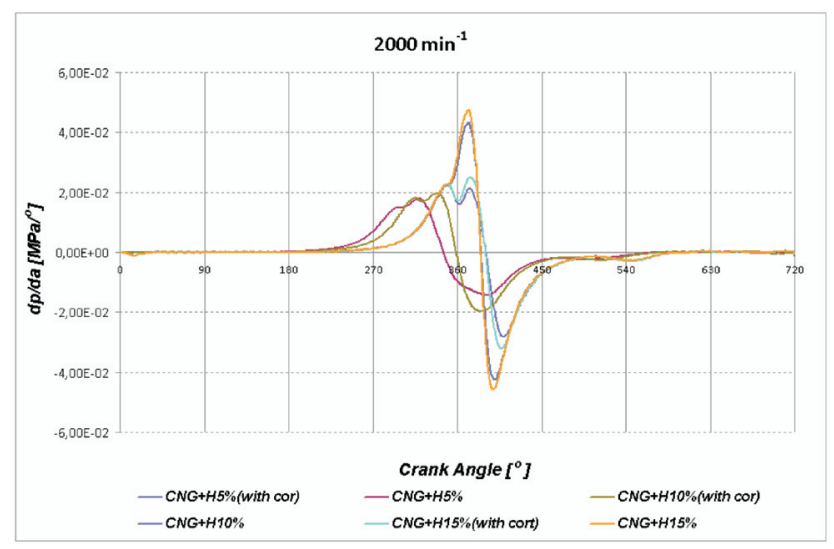

Fig. 3. Engine cycle pressure hardness

Rys. 3. Przyrost ciśnienia w cylindrze

As a result, the use of LPG, CNG or CNG-hydrogen mixtures offers more smooth and silent engine operation. That is confirmed by the indicated pressure and engine body accelerations, together with detailed combustion process analysis especially concerning the comparison of combustion time of gasoline and CNG and hydrogen mixture [4].

Tests done in the described project were completed for an engine fueled with the following fuels: gasoline, LPG, drgań typu ICP firmy PCB połączono z kondycjonerem firmy Roga Instruments typu PA 3000. Sygnały rejestrowano przy użyciu ośmiokanałowej karty akwizycji danych firmy National Instruments kontrolowanej przez aplikację napisaną w środowisku LabView.

Zmiany prędkości obrotowej i obciążenia realizowano na hamowni podwoziowej FLA 203 firmy BOSCH. Rysunek 1 przedstawia diagram przepływu danych omawianego stanowiska pomiarowego.

\section{Analiza wyników}

Zjawiska wibroakustyczne zachodzące w silniku przedstawiono na rys. 2.

Ciśnienie spalania jest jednym z głównych czynników determinujących drgania bloku silnika. Rysunek 3 przedstawia przebiegi dla różnych paliw przyrostu ciśnienia w cylindrze jako reprezentatywne wymuszenie.

Zmiany tych wymuszeń komplikują analizę procesu spalania przy użyciu sygnałów wibroakustycznych, które zmuszają do zastosowania skomplikowanych metod analizy w dziedzinie czasu lub kąta OWK.

Alternatywne paliwa obecnie są bardzo popularne. Z przeprowadzony do tej pory badań można zauważyć, że paliwa gazowe charakteryzują się szybszym i całkowitym wymieszaniem z powietrzem, dając w konsekwencji bardziej homogeniczną mieszankę dostarczaną do wszystkich cylindrów.

Użycie LPG, CNG lub mieszanek CNG i wodoru daje bardziej spokojną i cichą pracę silnika. Potwierdzono to przez wykreślone charakterystyki ciśnienia w cylindrze i przyspieszenia drgań bloku silnika oraz przez analizę porównawczą procesów spalania dla różnych paliw [4].

Badania przedstawione $\mathrm{w}$ niniejszej pracy przeprowadzono przy zasilaniu silnika następującymi paliwami: benzyną, LPG, CNG oraz mieszankami CNG i wodoru o zawartości wodoru 5, 10, 15, 20 i 30\% (zawartość objętościowa).

Dla zarejestrowanych przebiegów przyspieszeń drgań przeprowadzono obliczenia wspomnianych wcześniej bezwymiarowych współczynników, dla wybranego zakresu kątowego OWK zawierającego się od 320 do $420^{\circ} \mathrm{OWK}$.

Kompleksowa analiza procesu spalania silnika spalinowego jest możliwa tylko na podstawie analiz czasowoczęstotliwościowych. Precyzyjna dekompozycja amplitudowa-częstotliwościowa całego sygnału w dziedzinie czasowej umożliwia wyznaczenie zmian amplitudy, częstotliwości i fazy zjawiska. Jedną z metod selekcji czasowo-spektralnej jest ciągła transformata falkowa (CWT). Metoda ta może być porównana do filtrowania sygnału we względnie stałym oknie.

W transformacie falkowej pozycja filtru na mapie czasowo-częstotliwościowej jest definiowana przez współczynnik skali i przesunięcie okna. Razem z przesuwaniem okna analizy w kierunku wysokich częstotliwości szerokość okna maleje, zmniejszając rozdzielczość częstotliwości, a zwiększając rozdzielczość w czasie i odwrotnie.

Ten charakterystyczny element transformacji falkowej jest szczególnie użyteczny dla sygnałów niestacjonarnych 
CNG and CNG-hydrogen mixtures of compositions varying from $5,10,15,20 \%$ up to $30 \%$ (volumetric fraction of Hydrogen).

For the registered vibration acceleration signals a calculation of both the above mentioned non-dimensional factors has been performed. They were completed for a selected engine crank angle range starting from 320 up to $420 \mathrm{CA}$.

A complete analysis of an internal combustion engine is only possible based on the time-frequency signal charts. A precise amplitude-frequency decomposition of a complex signal in the time domain enables a representation of the amplitude, frequencies and elementary signals of momentary phases variations. One of the methods of the time-spectrum selection is a very popular wavelet transformation (CWT). It can be compared to a filtering with a constant relative bandwidth.

In the wavelet analysis the filter position on the timefrequency map is defined by scale and offset parameters. Together with the movement of the window in the direction of high frequency analysis a bandwidth increase makes the result in the frequency domain to decrease while the resolution in the time domain increases and vice versa.

This characteristic element of the wavelet transformation is useful in the case of simultaneous analysis of the

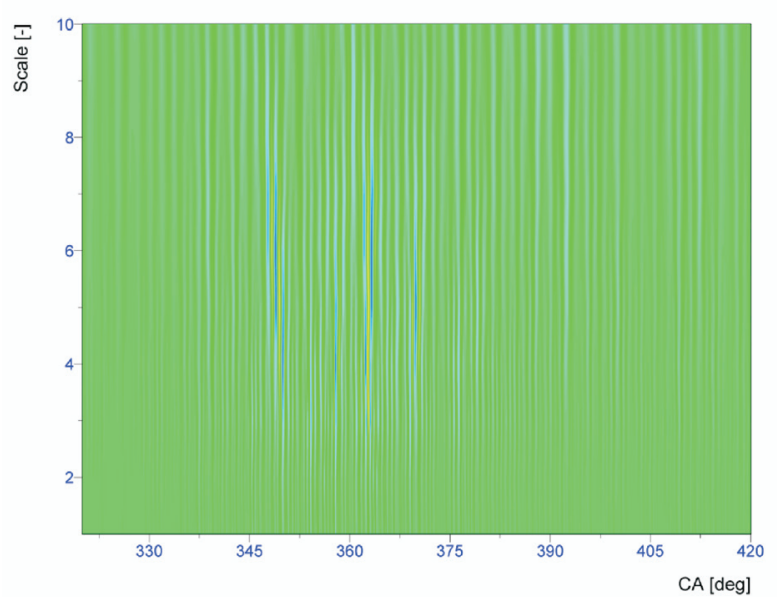

Fig. 5. Wavelet coefficient $\mathrm{C}_{\mathrm{ab}}$ for $\mathrm{CNG}$ and $5 \%$ hydrogen mixture; $\mathrm{y}$ axis, $\mathrm{rpm}=1500$, WOT

Rys. 5. Współczynniki falkowe $C_{a b}$ dla mieszanki CNG i 5\% wodoru; oś $y, n=1500 \mathrm{obr} / \mathrm{min}$, petne obciąienie

fast changing high frequency and the slowly changing low frequency processes generated by an internal combustion engine. Figure 4 demonstrates the results of the wavelet analysis of an engine block vibration for $\mathrm{CNG}$ with $5 \%$ hydrogen mixture combustion.

Non-dimensional coefficients CWT analysis has been performed for the above mentioned crank angle range (320 to $420 \mathrm{CA}$ ).

Plots 5-9 present the distribution of the wavelet coefficient $\mathrm{Cab}$ for $\mathrm{CNG}$ hydrogen blends estimated for the vibrations accelerations registered in the plane parallel to the cylinder axis. generowanych przez silnik spalinowy, kiedy następują szybkie zmiany w wysokich częstotliwościach i wolne zmiany w zakresie niskich częstotliwości. Rysunek 4 przedstawia wyniki transformaty falkowej sygnału przyspieszeń drgań bloku silnika przy zasilaniu mieszanką CNG i 5\% wodoru.

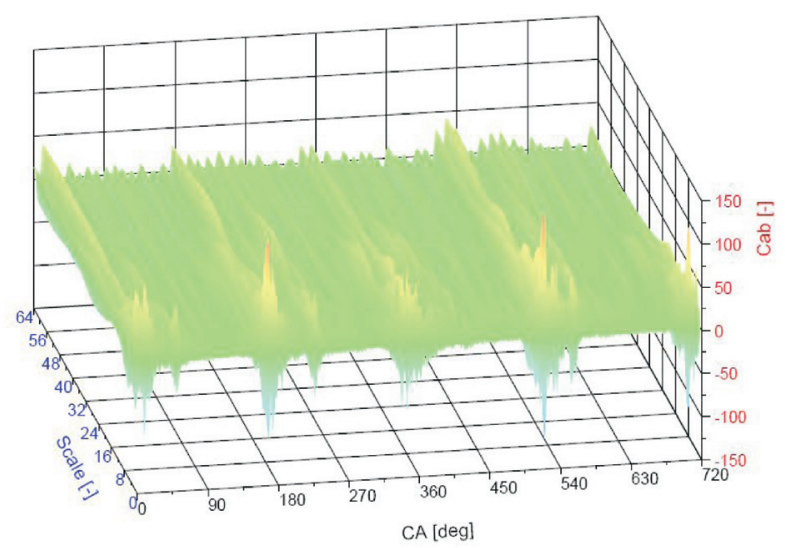

Fig. 4. Wavelet analysis of vibration signal acquired for CNG-hydrogen mixtures

Rys. 4. Wyniki analizy falkowej dla mieszanki CNG i wodoru

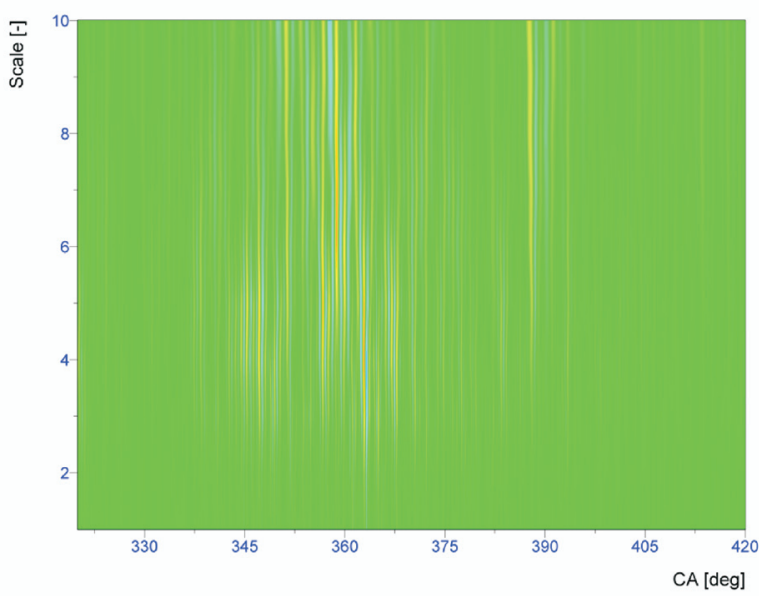

Fig. 6. Wavelet coefficient $\mathrm{C}_{\mathrm{ab}}$ for $\mathrm{CNG}$ and $10 \%$ hydrogen mixture; $\mathrm{y}$ axis, $\mathrm{rpm}=1500$, WOT

Rys. 6. Wspótczynniki falkowe $C_{a b}$ dla mieszanki CNG i $10 \%$ wodoru; oś $y, n=1500 \mathrm{obr} / \mathrm{min}$, petne obciązenie

Analizę bezwymiarowych współczynników CWT przeprowadzono we wspomnianym wcześniej zakresie kąta OWK (320 do $420^{\circ} \mathrm{OWK}$ ).

Wykresy 5-9 przedstawiają rozkład współczynników falkowych $\mathrm{C}_{\mathrm{ab}}$ dla mieszanek CNG i wodoru obliczonych dla sygnałów przyspieszeń drgań zarejestrowanych w płaszczyźnie równoległej do osi cylindra.

Obliczenia skalogramu i przyrostu współczynnika falkowego przeprowadzono w zakresie skali zredukowanej do 10.

Wartości skali powyżej 10 reprezentują częstotliwości zbliżające się do 0 . W tym zakresie częstotliwości nie występują zjawiska wpływające na wyniki analiz. 


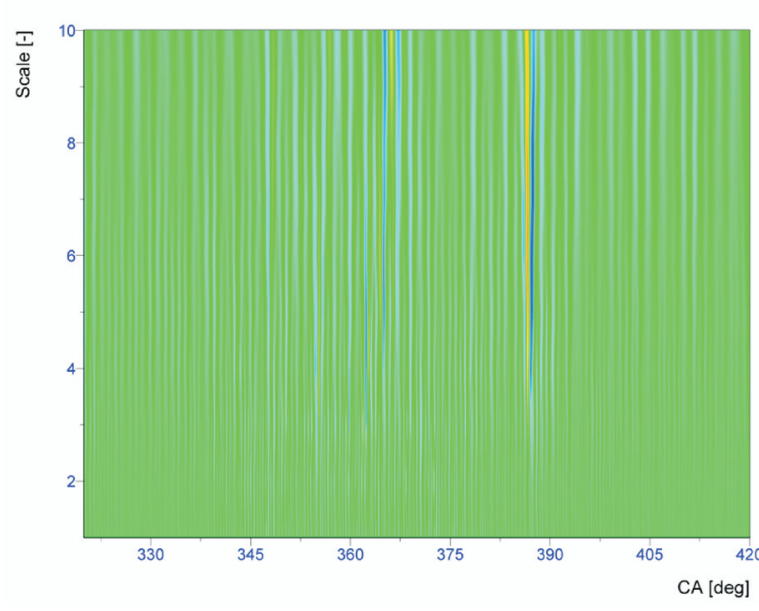

Fig. 7. Wavelet coefficient $\mathrm{C}_{\mathrm{ab}}$ for $\mathrm{CNG}$ and $15 \%$ hydrogen mixture; $\mathrm{y}$ axis, $\mathrm{rpm}=2000$, WOT

Rys. 7. Wspótczynniki falkowe $C_{a b}$ dla mieszanki CNG i $15 \%$ wodoru; oś $y, n=2000 \mathrm{obr} / \mathrm{min}$, petne obciąienie

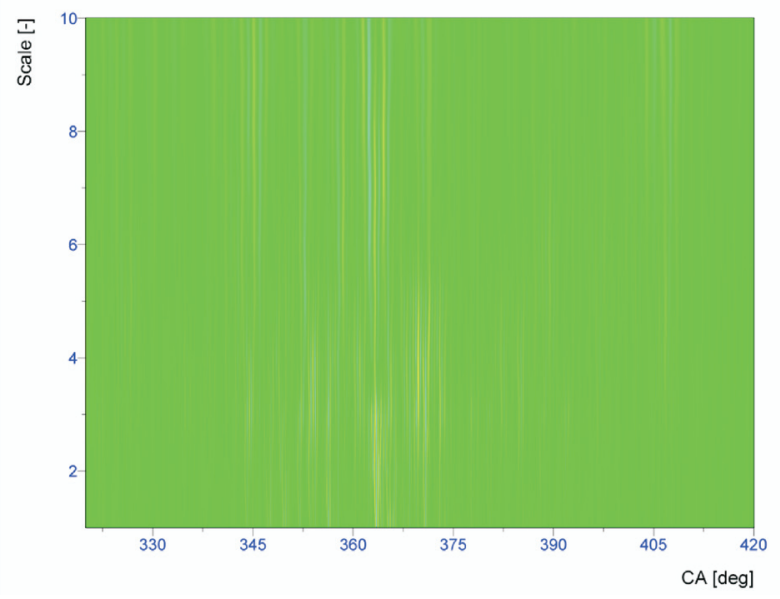

Fig. 9. Wavelet coefficient $\mathrm{C}_{\mathrm{ab}}$ for $\mathrm{CNG}$ and $30 \%$ hydrogen mixture; y axis, rpm $=2000$, WOT

Rys. 9. Wspótczynniki falkowe $C_{a b}$ dla mieszanki CNG i $30 \%$ wodoru; oś $y, n=2000 \mathrm{obr} / \mathrm{min}$, petne obciążenie

The scalogram, and the wavelet coefficient ratio calculations were done for the scale range reduced to 10 .

The values over 10 represent the frequencies approaching 0 . In that frequency range no phenomena influencing the results of the selected analysis can be found.

Plots 10-13 present the traces of the increase wavelet coefficient ratio and the scalogram value in the tested $\mathrm{x}$ and y directions.

Additionally, plots $14-17$ present the maximum values of the Increase Wavelet Ratio and the scalogram determined for different fuels.

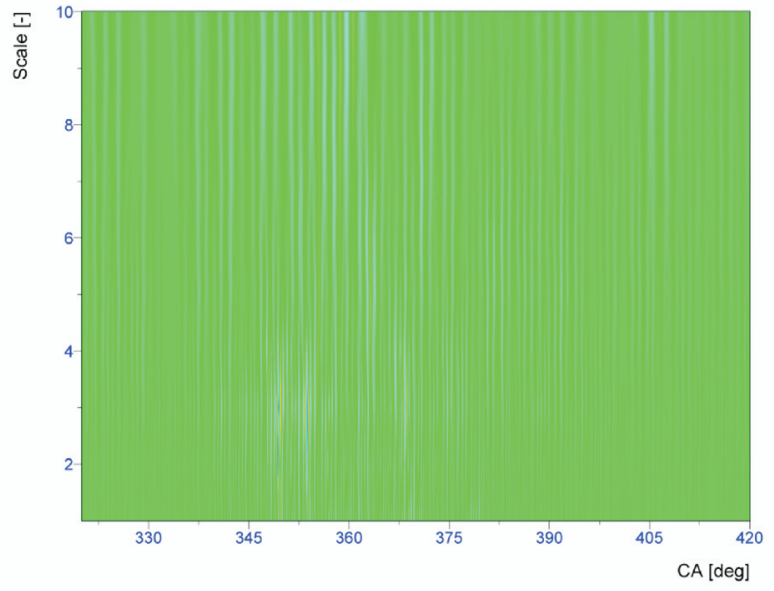

Fig. 8. Wavelet coefficient $\mathrm{C}_{\mathrm{ab}}$ for $\mathrm{CNG}$ and $20 \%$ hydrogen mixture; $\mathrm{y}$ axis, $\mathrm{rpm}=2000$, WOT

Rys. 8. Wspótczynniki falkowe $C_{a b}$ dla mieszanki $C N G$ i $20 \%$ wodoru; oś $y, n=2000 \mathrm{obr} / \mathrm{min}$, petne obciażenie

Wykresy 10-13 przedstawiają przebiegi przyrostu współczynnika falkowego i skalogramu w płaszczyźnie x i y.

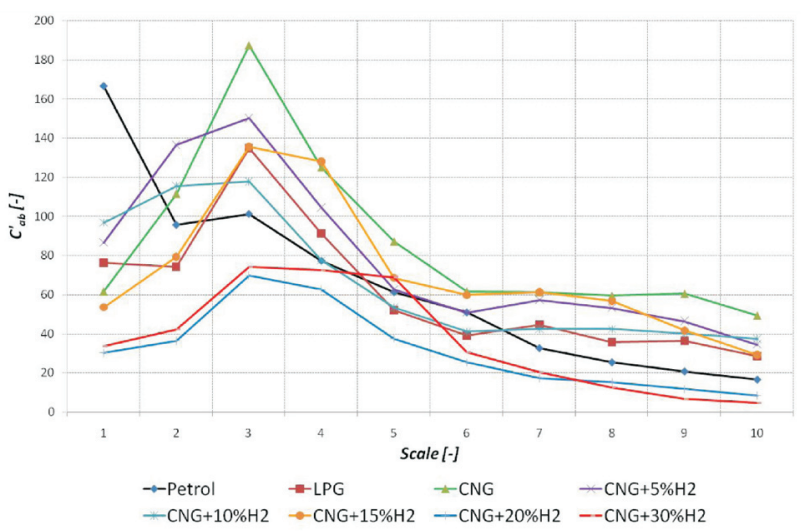

Fig. 10. Increase Wavelet Ratio $\mathrm{C}{ }_{\mathrm{ab}}$ vs. scale for different fuels; $\mathrm{x}$ axis Rys. 10. Przyrost wspótczynnika falkowego $C^{\prime}{ }_{a b}$ w funkcji skali dla różnych paliw; oś $x$

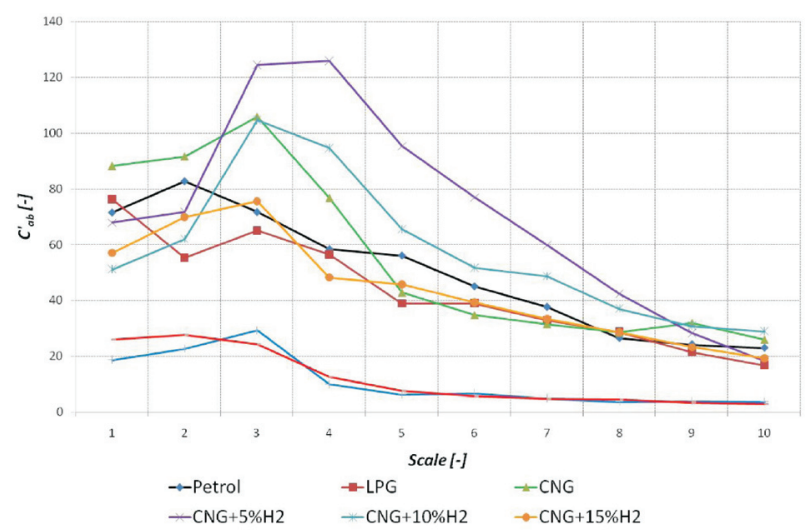

Fig. 11. Increase Wavelet Ratio C' ${ }_{\text {ab }}$ vs. scale for different fuels; $\mathrm{x}$ axis Rys. 11. Przyrost wspótczynnika falkowego $C^{\prime}{ }_{a b}$ w funkcji skali dla różnych paliw; oś $y$ 


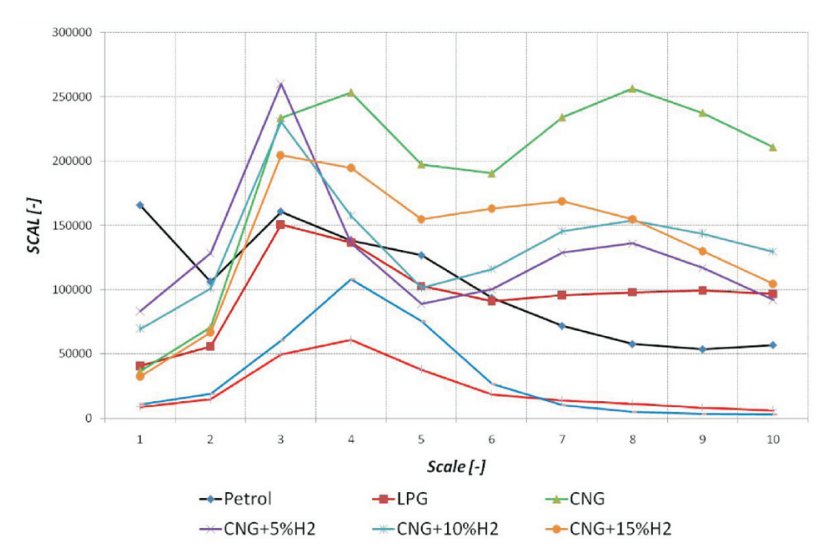

Fig. 12. Scalogram traces for different fuels; $\mathrm{x}$ axis

Rys. 12. Skalogram dla różnych paliw; oś $x$

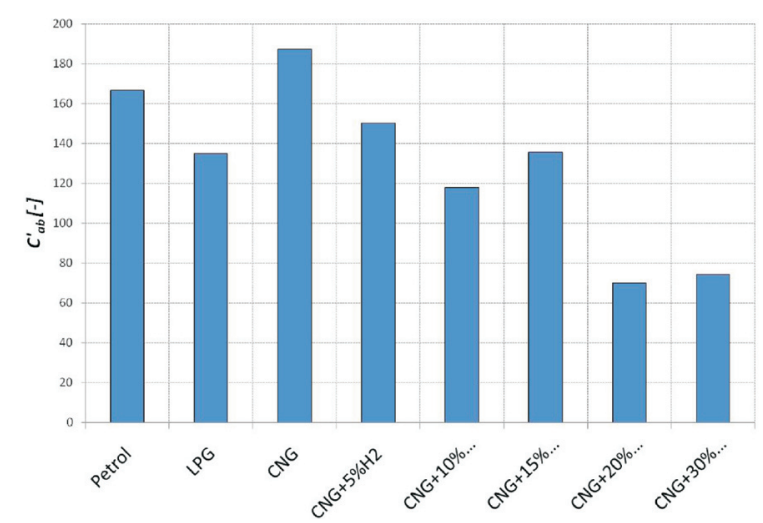

Fig. 14. Maximum value of the Increase Wavelet Ratio $\mathrm{C}^{\prime}{ }_{\mathrm{ab}}$ for different fuels; $\mathrm{x}$ axis

Rys. 14. Maksymalne wartości przyrostu wspótczynnika falkowego $C^{\prime}{ }_{a b}$ dla różnych paliw; oś $x$

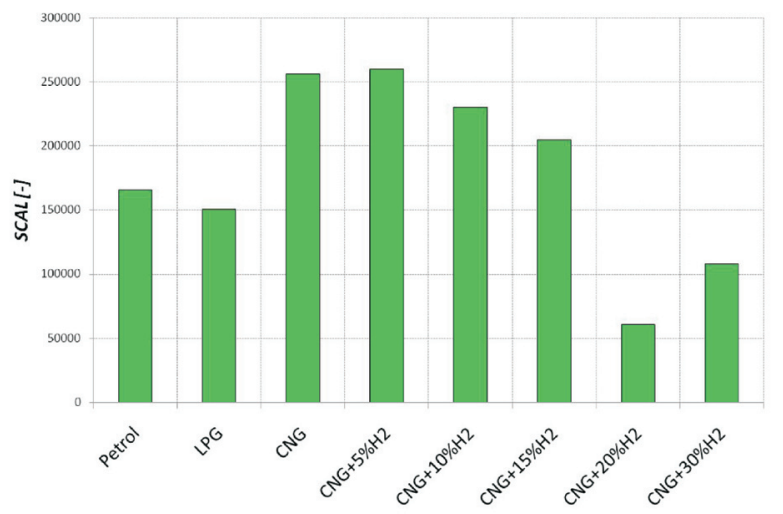

Fig. 16. Maximum value of the scalogram for different fuels; $\mathrm{x}$ axis Rys. 16. Maksymalne wartości skalogramu dla różnych paliw; ośx

\section{Conclusions}

The efficiency of the presented method strongly depends on a proper selection of the analysis window and the basic wavelet function. Following its changes enables a selection of the best control strategies for both the injection time and the ignition timing for the recognized type of fuel

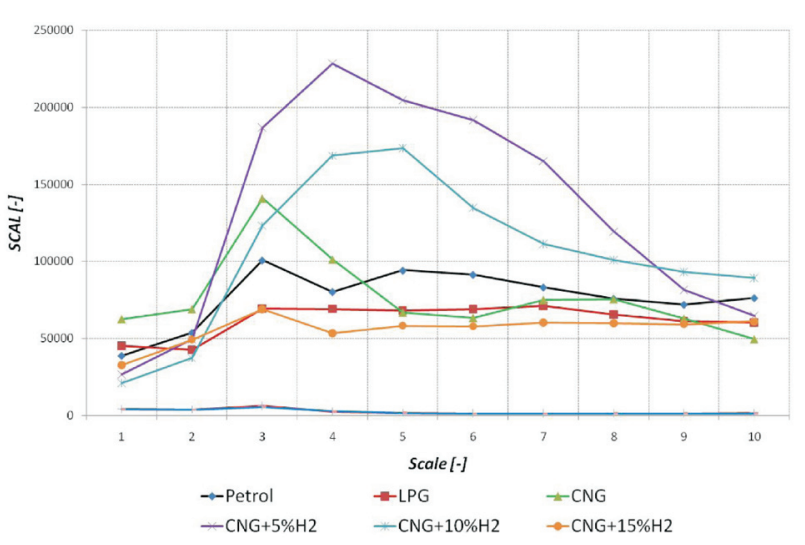

Fig. 13. Scalogram traces for different fuels; y axis Rys. 13. Skalogram dla różnych paliw; oś y

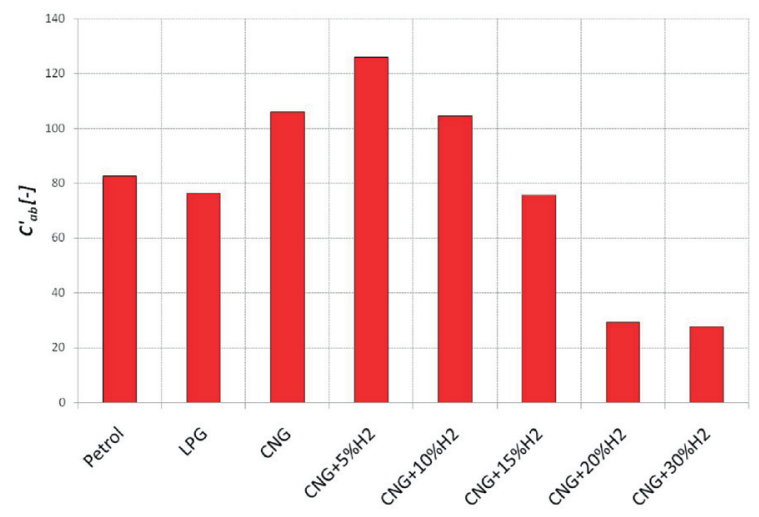

Fig. 15. Maximum value of the Increase Wavelet Ratio $\mathrm{C}{ }_{\mathrm{ab}}$ for different fuels; $y$ axis

Rys. 15. Maksymalne wartości przyrostu wspótczynnika falkowego $C_{a b}{ }^{\prime}$ dla różnych paliw; oś $y$

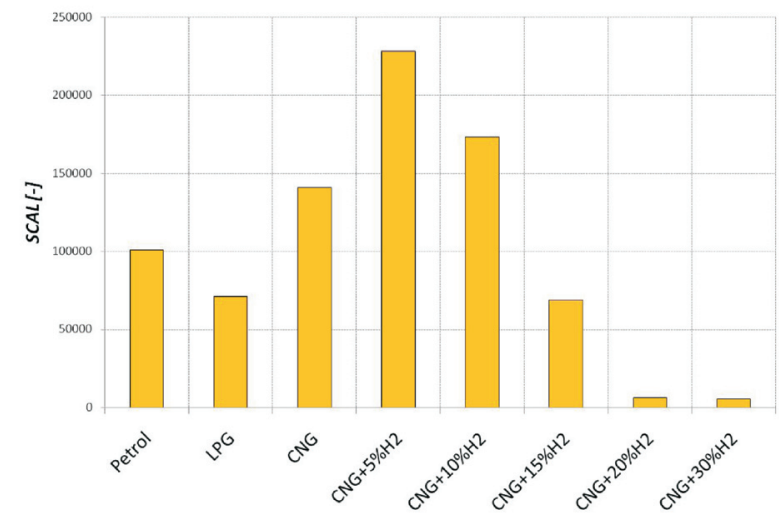

Fig. 17. Maximum value of the scalogram for different fuels; $y$ axis Rys. 17. Maksymalne wartości skalogramu dla różnych paliw; oś y

Dodatkowo na skalogramach (rys. 14-17) przedstawiono maksymalne wartości przyrostu współczynnika falkowego dla różnych paliw. 
(particularly when the fuel choose bottom will damage or will change compositions of hydrogen mixtures). The use of CWT in normal operating conditions of the vehicle is a complex process. The tests completed in the project show, that for the fuel type recognition it is sufficient to use the proposed factors. The best sensitivity for the changes of the engine block vibration level is represented by the increase wavelet coefficient ratio, $\mathrm{C}_{\mathrm{ab}}$.

Moreover, research done so far leads to the following conclusions:

- the in-cylinder pressure variations essentially influence the value of the engine block vibration signal,

- the possibility of a precise time-frequency analysis of the vibration signals depends on the signal sampling rate during the acquisition,

- for the engine operation on CNG-hydrogen blends for the proportions: $\mathrm{CNG}+20 \% \mathrm{H}_{2}$ and $\mathrm{CNG}+30 \% \mathrm{H}_{2}$, the level of combustion noise reduction is clearly noticable.

\section{Nomenclature/Skróty i oznaczenia}

CNG compressed natural gas/sprężony gaz ziemny

$\mathrm{C}_{\mathrm{ab}} \quad$ wavelet coefficient/wspótczynnik falkowy

LPG liquefied petrolum gas/gaz skroplony

SCAL scalogram/skalogram

CWT continuous wavelet transform/Ciagta Transformata Falkowa

\section{Wnioski}

Sprawność prezentowanej metody bardzo zależy od właściwego wyboru okna analizy i wyboru falki podstawowej. Dalsze zmiany dają możliwość wyboru strategii działania dla czasu otwarcia wtryskiwacza oraz kąta wyprzedzenia zapłonu dla rozpoznanego typu paliwa (szczególnie, kiedy uszkodzeniu ulegnie przełącznik rodzaju zasilania lub nastąpi zmiana składu paliwa). Użycie CWT w trakcie normalnych warunków pracy pojazdu jest skomplikowane. Wykonane badania wskazują, że rozpoznawanie paliwa zasilającego przy użyciu zaproponowanych współczynników jest satysfakcjonujące. Największą czułość na zmiany poziomu drgań ścianki bloku silnika prezentuje przyrost współczynnika falkowego $\mathrm{C}{ }_{\mathrm{ab}}$.

Ponadto wykonane badania prowadzą do następujących wniosków:

- zmiany ciśnienia w cylindrze mają wpływ na drgania korpusu silnika

- możliwość precyzyjnej analizy czasowo-częstotliwościowej sygnałów przyspieszeń drgań zależy od częstotliwości próbkowania

- dla silnika pracującego przy zasilaniu mieszanką CNG i wodoru przy zawartościach 20 i $30 \% \mathrm{H}_{2}$ poziom hałasu jest zauważalny.

Artykut recenzowany

\section{Bibliography/Literatura}

[1] Gao Y., Randall R. B.: Reconstruction of Diesel Cylinder Pressure Using a Time Domain Smoothing Technique. Mechanical System and Signal Processing, Vol. 13(5), 1999.

[2] Flekiewicz M., Madej H.: Estimation of IC engine combustion process using vibroacoustic techniques. Silesian University of Technology Papers.vol.48, 2003.

[3] Flekiewicz M., Madej H.: Introduction to identification of IC engine noise. Scie. Conf. of Modal Analysis, Kraków 2004.

[4] Flekiewicz M., Kubica G., Wilk K.: An attempt of prediction of exhaust gases composition by petrol and LPG powered SI engine. Papers of the VIIth Inter. Scie. Conf. GAS ENGINE 2006.

[5] Flekiewicz M., Flekiewicz B., Fabiś P.: Engine block vibration level as a tool for fuel recognition. SAE Paper 2007-01-2162, 2007.

[6] Ozawa H., Nakada T.: Pseudo cylinder pressure excitation for analyzing the noise characteristics of the engine structure. JSAE Review 20, 1999.

Mr. Paweł Fabis, DEng. - doctor in the Faculty of Transport at Silesian University of Technology. Dr inż. Pawet Fabiś - adiunkt na Wydziale Transportu Politechniki Śląskiej.

e-mail: pawel.fabis@polsl.pl
[7] PCB Piezotronics Vibration Division - Product Catalog, USA, New York 2003.

[8] Mc Carthy D.J., Lyon R.H.: Recovery of impact signatures in machine structures. Mechanical Systems and Signal Processing, 9, 1995.

[9] Batko W., Ziółko M.: Zastosowanie teorii falek w diagnostyce technicznej. Monografie Wydziału Inżynierii Mechanicznej i Robotyki, Problemy Inżynierii Mechanicznej i Robotyki, Kraków 2002.

Mr. Marek Flekiewicz, DEng. - doctor in the Faculty of Transport at Silesian University of Technology.

Dr inż. Marek Flekiewicz - adiunkt na Wydziale Transportu Politechniki Śląskiej. e-mail:marek.flekiewicz@polsl.pl

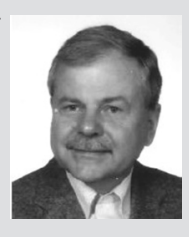

Mr. Bartosz Flekiewicz, DEng. - Engineer in the Auto Gaz Slask.

Dr inż. Bartosz Flekiewicz - specjalista ds. technicznych w Auto Gaz Ślask.

e-mail: bflekiewicz@autogaz.com.pl 